\title{
Single amino-acid makes big difference in patent court
}

Tokyo. The US biotechonology company Genentech has suffered an unexpected defeat in Japan in a battle to defend its patent rights on the heart treatment drug tissue plasmogen activator (TPA).

The decision has highlighted the tendency of the Japanese system to place very narrow limits on the coverage of patents. The rejection of Genentech's claim that its patent had been infringed by Sumitomo Pharmaceutical hinged on a difference of only one in the partial amino-acid sequences of its own and the Japanese product.

The ruling was made on 27 October by a local district court judge in Osaka. The decision surprised everyone - including Sumitomo - as three years ago the US company won a very similar suit against another Japanese company, Toyobo, which was subsequently forced to halt its production of TPA (Nature 354, 4; 1991).

Genentech made worldwide patent applications in 1983 for its TPA, made with recombinant-DNA technology. But the Japanese patent office refused to accept Genentech's bid for a patent covering every form of TPA, including that which occurs naturally. Genentech had to revise its Japanese patent application several times by providing key amino-acid sequences before the patent was accepted in January 1991.

In the case of Toyobo's TPA, produced under a licence from the US company Genzyme Corporation, the amino-acid sequence was identical to that in Genentech's patent. But Sumitomo's TPA, made with technology licensed from the Wellcome Foundation in the United Kingdom, differs in one position of the amino-acid sequence.
The judge concluded that this was sufficient grounds for rejecting Genentech's claim of infringement.

The judge's decision has caused surprise largely because there does not appear to be any significant difference in the clinical effect of the two forms of the TPA; indeed the judge ruled that he could find no "meaningful" difference in clinical effect. Nevertheless, he still argued that it could not be said that the immunological characteristics and biological activity of the two forms of TPA are the same.

Genentech has not yet decided whether to appeal against the decision. The market for TPA in Japan is only about $¥ 6.5$ billion (US\$65 million) a year and falling - many Japanese doctors do not use clot-dissolving agents such as TPA, preferring to use percutaneous translumino coronary angioplasty, an invasive technique where a balloon is inflated to dilate the narrowed artery after insertion via a catheter.

But few would be surprised if Genentech does decide to appeal, as it has been championing the protection of intellectual property rights and pushing for reform of the Japanese patent system.

Patents tend to be very narrowly defined in Japan so companies can often circumvent patents held by competitors with only very slight modifications of a product or process.

Nevertheless, Sumitomo Pharmaceutical was still caught off balance by the decision, which had been widely expected to go in Genentech's favour. Sumitomo is now hurriedly producing promotional pamphlets and designing packaging for their product.

David Swinbanks

\section{Eugenics law puts Beijing meeting at risk}

London. The International Genetics Federation (IGF) may change its plans to hold the 1998 International Congress of Genetics in Beijing, following the Chinese government's decision last month to approve a law forbidding people with mental disabilities or contagious diseases to marry.

According to the official Xinhua news agency, the new law will "help reduce births of physically or mentally abnormal babies". The National People's Congress stated that it will also help to "upgrade the general qualities of the new population".

The law is a diluted version of a bill first proposed in December 1993 (see Nature 367, 3; 1994). Following widespread protests from the international scientific community, the idea seemed to have been dropped.

The IGF chose China to host the congress, held every five years, at its last con- gress in Birmingham in 1993. But, concerned about the possible introduction of a 'eugenics' law, it subsequently obtained an agreement that, prior to the 1998 congress, the Chinese organizers would issue a statement reassuring the international community on the government's plans.

In a statement issued last weekend, the IGF says that the passing of the new law "has given the IGF new cause for concern", adding that it has initiated a "reappraisal" of China as an appropriate location for the 1998 congress.

The IGF has recently launched several initiatives designed to promote genetics at an international level. One is to take steps to increase the number of scientists from developing countries attending its congresses. Another is to bring pressure to bear on countries where there is potential for abuse of genetics.

\section{Former CNRS chief rejects criticism, hits at funding cuts}

Paris. François Kourilsky, former directorgeneral of the French Centre National de la Recherche Scientifique (CNRS), last week claimed that the government is misrepresenting the causes of the current financial crisis at the agency in order to cover up its decision to reduce funding for science.

Kourilsky was speaking after François Fillon, the minister of higher education and research, had blamed the crisis on past management of CNRS, which he described as "lax" and "calamitous". Kourilsky described the allegation as "absurd", and added that, if

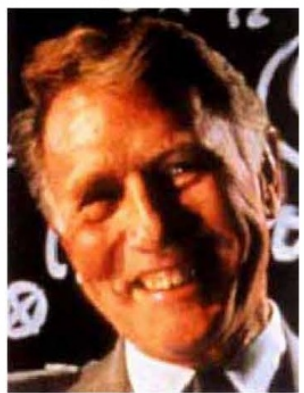

Kourilsky: charges of laxity are 'absurd'. the government wants to cut research funding, it should say so.

The crisis has arisen because of a decision by Guy Aubert, the agency's new directorgeneral, that researchers can spend no more than 60 per cent of funds allocated for this year. The move was made to deal with a FFr550-million (US\$106-million) gap in CNRS's finances caused by the government's failure to make promised payments.

Kourilsky argues that the state - not the CNRS - should make up the difference. In previous years he filled the gap by taking money from CNRS central funds and sees no reason why Aubert should not have done likewise. Indeed, following protests from researchers, Fillon last month authorized FFr360 million to be taken from central funds.

Kourilsky also claims that the central question is the future of research in France. "Research policy cannot be reduced to making economies, and lack of financial support cannot be hidden behind allegations of past management," he says.

Researchers were due to hold a national strike earlier this week to protest about a reduction in support. Another concern is that the government may be intending to restructure CNRS and reduce the number of its laboratories from 1,300 to as few as 400 , with the control of many passing directly to universities.

Observers say that Fillon is under pressure to propose reforms because Jacques Chirac, a conservative candidate for next year's presidential elections, wants to refer to research in his election manifesto - not least because Jacques Delors, the likely socialist candidate, will probably do so, having made research a major part of his recent white paper on European competitiveness (see Nature 366, 599; 1993). Declan Butler 